\title{
ФIHAHCOBE ПРАВО
}

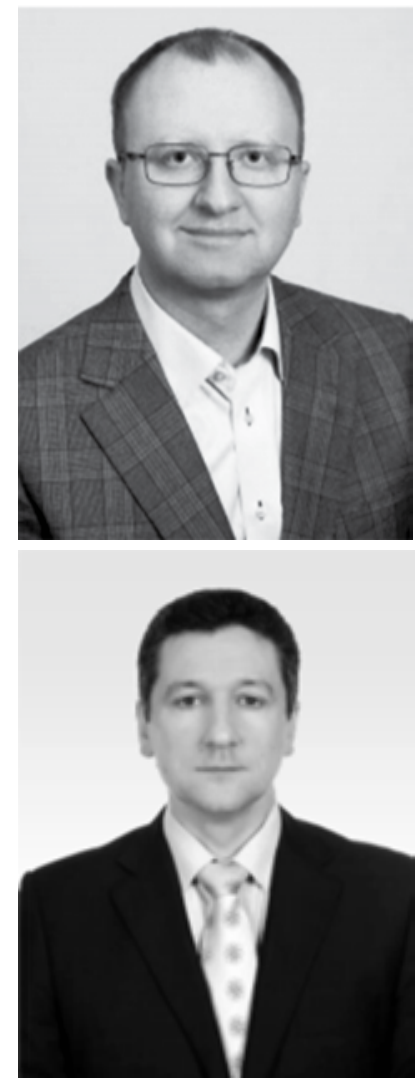

\author{
Аньрій Ковамьчук, \\ Аоктор юричичних наук, профресор, \\ заслужений $і я ч$ науки і техніки України, \\ профресор кафеєри правосуц厶я Аержавного \\ університету інфрраструктури та технологій
} ORCID: 0000-0003-2332-7295

\author{
Семен Стеценко, \\ Аоктор юричичних наук, професор, \\ заслужений Аіяч науки і техніки України, \\ член-кореспоньент Національної акацемії \\ правових наук України, \\ суцАя Верховного Суду
}

ORCID: 0000-0002-4350-2321

https://doi.org/10.32782/2306-9082/2021-41-9

УДК 334: 340.1

\section{Правова мотивація підприємництва на засадах блокчейн-технологій}

Підприємництво (підприємницька діяльність) - це систематична, на власний ризик господарська діяльність, самостійна ініціатива, що здійснюється суб'єктами господарювання 3 метою досягнення економічних і фінансових результатів та одержання прибутку. Підприємництво як модель суспільних відносин гостро потребує правової підтримки на засадах законодавчо встановлених принципів, правил і норм, які б правовим чином впорядковували такі відносини. Підприємництву органічно властивий інноваційний характер, тобто нові форми та способи господарювання, що зумовлює потребу системної правової підтримки та мотивації. Така очевидність зареєстрована у законодавчому порядку [1]. Попри те, що підприємництво за своєю суттю демонструє інноваційний характер, нові підходи та способи господарювання, водночас зазначимо, що здебільшого юридичне оформлення тих чи інших відносин 
підприємницької діяльності страждає недосконалістю, передусім унаслідок взаємного ігнорування юридичної та економічної наук. При цьому пропозиції економістів не завжди враховують вимоги правознавства, водночас юридичні формулювання так само обходять увагою економічний зміст того чи того правовідношення [2].

Нині світ вступив у принципово нову інноваційно-технологічну епоху, коли наявність природних ресурсів i ціна трудових ресурсів перестали бути визначальними факторами цивілізаційного поступу. Набуває відчутного розмаху нова інформаційно-інноваційна революція, ключовим мотиватором якої виступають блокчейн-технології. При цьому безпрецедентно новітні технології отримують реальне підгрунтя за умови сталої підтримки державно-правових регуляторів.

Залежно від того, якою мірою держава через правові інститути та механізми здійснює системну підтримку цивілізаційних викликів, у відповідній країні відкривається «вікно» інноваційних можливостей. При цьому вкрай небажано допускати (а це вже місія державно-правових імперативів), щоб базовий капітал і підприємництво концентрувались у руках небагатьох представників бізнес- чи політичної еліти.

Украй важливо, щоб правова мотивація вітчизняного підприємництва все більшою мірою базувалася на технології «блокчейн» та перспективах застосування криптовалют [3]. Блокчейн - це сформований за визначеними правилами й принципами безперервний та послідовний ланцюжок блоків, які містять принципово важливу інформацію (зокрема, про угоди та їх характеристикиусферіпідприємництва).

Тому вже давно виникла потреба у визначенні правової природи віртуальних валют та блокчейн-технологій.

Держави, націлені на всебічну підтримку підприємництва, переходять від експериментів до легалізації та практичного впровадження блокчейн-технологій у найбільш важливих сферах господарської та економічної діяльності [4]. Наприклад, в Японії технологія криптовалютного блокчейну є невід'ємною складовою частиною державної стратегії розвитку цифрових фінансів. У квітні 2017 р. японське законодавство визнало криптовалюти одним із ключових інструментів фінансових розрахунків. Натепер Агентство фінансових послуг Японії (FSA) активізує правову мотивацію криптоіндустрії на засадах блокчейн-технологій.

Також інші цивілізовані країни націлені не перешкоджати розвитку криптоіндустрії на засадах блокчейн-технологій. Зокрема, Великобританія забезпечує синергію блокчейн-технології зі штучним інтелектом (AI) та «Інтернетом речей» (IoT). Водночас окремі прояви обмежувального підходу спостерігаються у США, де криптовалютні операції не заборонені, але скрупульозно регулюються. Водночас, попри наявність трьох регуляторів та складні умови ведення криптовалютного бізнесу, США натепер $є$ лідером за кількістю наявних блокчейн-компаній.

Також зазначимо, що Китайська мережа блокчейн-платформ (BSN) займається розробкою та створенням інфраструктури децентралізованих токенів та планує у другій половині 2021 р. запустити бета-версію цифрової валюти. Китайська мережа блокчейн-платформ (BSN) займається розробкою та створенням інфраструктури децентралізованих додатків i токенів та планує уже в другій половині 2021 р. випустити бета-версію цифрової валюти центрального банку (CBDC) Китаю.

Водночас великі китайські гравці цього ринку стали переносити в Іран свої ферми, оскільки там електроенергія вчетверо дешевша. На поточний момент, імовірно, в Ірані знаходиться 14 величезних майнінгових ферм, які 
споживають сумарно близько $300 \mathrm{MB}$ енергії, що можна порівняти з містом 3 населенням 100000 осіб [5]. 3 огляду на ситуацію на ринку криптовалюти, проблема в найближчому майбутньому може посилитися.

Зазначимо, що блокчейн - це система розподіленого реєстру і водночас ланцюг блоків. Це своєрідний регістр, що базується на потужній комп'ютерній мережі. Тобто йдеться про інноваційний публічний реєстр, що концентрує відповідну базу даних та здійснених інформаційних транзакцій відповідної криптовалюти. Нині з'являються цілі галузі, що базуються і функціонують на базі криптовалютних операцій.

Реальне формування фінансових ресурсів, їх акумулювання у фінансовий капітал набуває такого розмаху, що для ї урегулювання необхідно активно використовувати законодавчо-правові інструменти та механізми. Водночас по мірі все більш інтенсивного й широкого застосування криптовалют на основі блокчейну неминучий стрімкий дрейф від диктату центрального банку до всезагальної монетарної децентралізації. Така об’єктивна даність цивілізаційного розвитку потребує дієвого фінансово-правового регулювання криптовалютного ринку. Така очевидність уже була певною мірою проаналізована нами [3].

По мірі все білыш інтенсивного й широкого застосування криптовалют на основі блокчейну неминучий стрімкий дрейф від диктату центрального банку до всезагальної монетарної децентралізації. Натепер десятки країн офіційно визнали один 3 різновидів криптовалюти - біткоїн законним платіжним засобом і створили загальноприйнятну основу для ефективного регулювання криптовалютного ринку.

Розвиток криптовалютної мережі зумовлює цивілізаційну приреченість втрати доларом та євро монопольної ролі у міжнародних розрахунках. Водночас така очевидність зумовлює нагальну потребу законодавчо-правового дисциплінування (і насамперед державної легалізації) криптовалютного ринку на вітчизняних теренах. Тому неідеальною видається політика Національного банку України щодо фактичного ігнорування таких цивілізаційних новацій, як майнінг криптовалюти, блокчейн-технології, як важливих і перспективних фінансових інструментів. Також ця очевидність у нинішніх українських реаліях потенційно може використовуватись у корупційних цілях.

Blockchain технології - це передусім база даних, яка записує інформацію «шарами». Аби її підробити, треба підробити зовнішні «шари», що практично неможливо. База даних на основі блокчейну буде корисною для кадастрів, які фіксують персональну інформацію про підприємницьку діяльність.

Рей Даліо, глава найбільшого у світі хедж-фонду Bridgewater Associates, заявив у ході AMA-ceciï на Reddit, що за останнє десятиріччя біткоїн успішно зарекомендував себе як успішна альтернатива золоту. Він вважає, що флагманська криптовалюта може слугувати «диверсифікатором золота» та «сховищем багатства» в майбутньому. «Я думаю, что ВТС и некоторые другие цифровые валюты за последние десять лет зарекомендовали себя как интересные альтернативы активам, со сходными чертами и различиями с золотом и другими мобильными (в отличие от недвижимости) хранилищами богатства с ограниченным предложением. Поэтому биткоин может служить диверсификатором золота и другим подобным активам богатства», - зазначив інвестор-мільярдер Рей Даліо [6].

Отже, технології блокчейн - це передусім і головним чином публічний реєстр або база даних, що містить усю інформацію про транзакції відповідної криптовалюти. Одним натиском клавіші смартфона миттєво здійснюється (без комісіі) платіжна 
транзакція до будь-якої точки земної кулі, де налагоджена блокчейн-система. Тобто йдеться про ретрансляцію інформації, що попередньо записана у спеціальний блок даних фіксованого розміру - hash (хеш). Отже, «хешування», або математичне перетворення інформації в хешблоки, є обов'язковою умовою блокчейна.

Таким чином, нині активно формується своєрідний блокчейн-всесвіт, компактно представлений у глобальному Інтернеті. Саме на засадах блокчейн-технологій має здійснюватися правова мотивація підприємницької діяльності в Україні. Попри це, явно недостатньою натепер є увага української держави щодо фінансово-правової мотивації підприємництва на засадах криптографії, тобто системи забезпечення конфіденційності та автентичності інформації в Інтернеті на засадах блокчейн-технологій. Так, Міністерство цифрової трансформації лише ставить до відома, що 31 вересня 2021 р. держоргани в Україні не зможуть вимагати паперові документи, якщо вони є у людини у смартфоні.

Віце-прем'єр-міністр - Міністр цифрової трансформації Михайло Федоров вказує: «Перший крок - заборона держорганам вимагати від українців паперові документи, якщо у них є цифрові. На практиці це означає, що ваші цифрові документи діють завжди і скрізь; будь-яку послугу можна отримати онлайн; усі органи влади зможуть працювати з електронними документами, що мають інтерфейс перевірки необхідної інформації в держреєстрах; весь бізнес оцифровує свої внутрішні процеси». Міністр водночас констатує: «Для успішної цифровізації важливо вирішити питання із захистом персональних даних. Дія щодо цього $є$ найбезпечнішим продуктом, оскільки не зберігає персональних даних, а лише є транзитним шляхом, платформою, що відображає інформацію про вас у реєстрах» [7].
Зрозуміло, що цього явно не досить для реальної мотивації підприємництва на засадах блокчейн-технологій.

Натепер ми в Україні маємо екстенсивне (перманентно мінливе) законодавство. Водночас працездатне населення потерпає від порівняно невисоких заробітних плат і нерідко безробіття. Цим зумовлювалася украй низька купівельна спроможність широкого загалу i, як наслідок, стагнація національного виробництва. Таким чином, перед Україною, врешті-решт, зримо постав привід інноваційно-технологічного дефолту. I це при тому, що йдеться про територію в центрі Європейського континенту.

Та держава має цивілізаційні перспективи, коли активно функціонує товаропродукуюча сфера, заземляються передові найсучасніші технологічні регламенти, діє прогресивне законодавство та беруться до уваги перспективні міжнародні стандарти. Водночас податкова система має стимулювати модернізацію національного господарства. Лише за таких умов підприємства, фабрики, заводи в змозі працювати на новій технологічній базі і в принципово іншому (як правило, інноваційному) середовищі.

Отже, українська держава зобов'язана законодавчо забезпечити сприятливий для підприємництва діловий клімат, справедливі правила економічної конкуренції і головне адекватно реагувати на цивілізаційні виклики нової технологічної епохи. Світовий досвід успішних й економічно розвинутих держав показав, що регуляторна система в країні має бути сконструйована таким чином, щоб капітал крупних компаній активно підхоплював та інвестував технологічні інновації, а середній і малий бізнес домінував у реалізації підприємницьких нововведень. Саме на це має бути націлена правова мотивація вітчизняного підприємництва на засадах блокчейн-технологій. 


\section{Список використаних джерел}

1. Господарський кодекс України. Відомості Верховної Ради України. 2003. № 18 , ст. 144.

2. Ковальчук А.Т. Фінансове право: проблеми утвердження та ефективного застосування. Публічне право. 2017. № 1, С. 10-17.

3. Ковальчук А.Т., Стеценко С.Г. Фінансово-правові засади регулювання криптовалютного ринку. Публічне право. 2018. № 1. С. 85-92.

4. URL: https://ec.europa.eu/digital-sinqle-market/en/legal-and-regulatoryframework-blockchain.

5. UKR NET. 8.02.2021.

6. Миллиардер Рэй Далио назвал биткоин интересной альтернативой золоту. URL: https://www.bitbetnews.com/news-crypto/milliarder-rjej-dalio-nazval-bitkoininteresnoj-alternativoj-zolotu.html.

7. UKR NET. 28.01.2021.

Ковальчук А. Т., Стеценко С. Г. Правова мотивація підприємництва на засадах блокчейн-технологій

Стаття присвячена питанням пошуків шляхів правової мотивації підприємництва на засадах блокчейн-технологій. Акцентується увага на тій обставині, що нині світ вступив у принципово нову інноваційно-технологічну епоху, коли наявність природних ресурсів і ціна трудових ресурсів перестали бути визначальними факторами цивілізаційного поступу. Набуває відчутного розмаху нова інформаційно-інноваційна революція, ключовим мотиватором якої виступають блокчейн-технології.

Стверджується, що блокчейн - це сформований за визначеними правилами й принципами безперервний та послідовний ланцюжок блоків, які містять принципово важливу інформацію. Це своєрідний регістр, що базується на потужній комп'ютерній мережі. Тобто йдеться про інноваційний публічний реєстр, що концентрує відповідну базу даних та здійснені інформаційні транзакції відповідної криптовалюти.

Робиться висновок, що українська держава зобов'язана законодавчо забезпечити сприятливий для підприємництва діловий клімат, справедливі правила економічної конкуренції і головне - адекватно реагувати на цивілізаційні виклики нової технологічної епохи.

Ключові слова: правова мотивація, підприємництво, блокчейн, криптовалюта.

Ковальчук А. Т., Стеценко С. Г. Правовая мотивация предпринимательства на основе блокчейн-технологий

Статья посвящена вопросам поисков путей правовой мотивации предпринимательства на основе блокчейн-технологий. Акцентируется внимание на том обстоятельстве, что сейчас мир вступил в принципиально новую инновационно-технологическую эпоху, когда наличие природных ресурсов и цена трудовых ресурсов перестали быть определяющими факторами цивилизационного развития. Приобретает ощутимый размах новая информационно-инновационная революция, ключевым мотиватором которой выступают блокчейн-технологии.

Утверждается, что блокчейн - это сформированная по определенным правилам и принципам непрерывная и последовательная цепочка блоков, которые содержат принципиально важную информацию. Это своеобразный регистр, основанный на мощной компьютерной сети. То есть речь идет об инновационном публичном реестре, который концентрирует базу данных и осуществленные информационные транзакции соответствующей криптовалюты.

Делается вывод, что украинское государство обязано законодательно обеспечить благоприятный для предпринимательства деловой климат, справедливые правила экономической конкуренции и главное - адекватно реагировать на цивилизационные вызовы новой технологической эпохи.

Ключевые слова: правовая мотивация, предпринимательство, блокчейн, криптовалюта. 
Kovalchuk A., Stetsenko S. Legal motivation of entrepreneurship on the basis blockchain technologies

The article is devoted to the search for ways of legal motivation of entrepreneurship on the basis of blockchain technologies. Emphasis is placed on the fact that today the world has entered a fundamentally new era of innovation and technology, when the availability of natural resources and the price of labour have ceased to be determining factors in the progress of civilization. A new information and innovation revolution are gaining momentum, the key motivator of which is blockchain technology.

It is argued that a blockchain is a continuous and consistent chain of blocks formed according to certain rules and principles, which contain fundamentally important information. It is a kind of register based on a powerful computer network. That is, it is an innovative public register that concentrates the relevant database and information transactions of the relevant cryptocurrency.

It is concluded that the Ukrainian state is obliged by law to provide a favourable climate for business, fair rules of economic competition, and most importantly - to adequately respond to the challenges of civilization of the new technological era.

Key words: legal motivation, entrepreneurship, blockchain, cryptocurrency. 